\title{
Measurement of Red Cell Lifespan and Aging
}

\author{
Robert S. Franco \\ Division of Hematology/Oncology, Department of Internal Medicine, University of Cincinnati College of Medicine, Cincinnati, OH, USA
}

\section{Keywords}

Red cell lifespan - Chromium - Biotin .

Red cell senescence $\cdot$ Red cell aging

\section{Summary}

The measurement of red blood cell (RBC) survival has a long history, and a wide variety of methods have been utilized for this purpose. Current methods are of 2 types. First, those that label a representative sample of RBCs of all ages from the blood and then measure their rate of disappearance upon reinfusion. This category includes the ${ }^{51} \mathrm{Cr}$ and biotin labels. Second, those that use a metabolic precursor or product to determine the turnover of hemoglobin. Examples of these are carbon monoxide production and incorporation of labeled glycine. Recent studies with the covalent, nonradioactive biotin label show its unique suitability for both the accurate measurement of red cell survival and the determination of changes in red cell properties as they age in vivo.

\section{Introduction}

Human red blood cells (RBC), after differentiating from erythroblasts in the bone marrow, are released into the blood and survive in the circulation for approximately 115 days. In humans and some other species, RBC normally survive in a nonrandom manner. This means that all of the RBC in an age cohort are removed by the reticuloendothelial system at about the same time. In practice there is considerable variation in

\author{
Schlüsselwörter \\ Lebensdauer von Erythrozyten · Chrom · Biotin . \\ Erythrozytenseneszenz · Erythrozytenalterung
}

\section{Zusammenfassung}

Die Messung des Überlebens von Erythrozyten hat eine lange Vorgeschichte, und eine Vielzahl an Methoden sind bisher für diesen Zweck zum Einsatz gekommen. Die aktuell angewandten Methoden können in 2 Kategorien eingeteilt werden. Zum einen existieren jene Methoden, die eine repräsentative Probe von Erythrozyten aller Altersstufen im Blut markieren und anschließend die Rate ihres Verschwindens nach Reinfusion messen. Als Marker werden etwa ${ }^{51} \mathrm{Cr}$ und Biotin verwendet. Die zweite Kategorie umfasst jene Methoden, die einen metabolischen Precursor oder ein Endprodukt nutzen, um den Hämoglobinumsatz zu bestimmen. Beispiele hierfür sind die Kohlenmonoxid-Produktion und die Aufnahme von markiertem Glycin. Jüngste Studien mit der kovalenten, nicht radioaktiven Biotin-Markierung zeigen deren einzigartige Eignung für sowohl die genaue Messung des Überlebens von Erythrozyten als auch die Bestimmung von Veränderungen in den Eigenschaften der Erythrozyten während des Alterungsprozesses in vivo.

the lifespan of human RBC. In a normal individual with a mean RBC lifespan of 115 days, this value may vary between 70 and 140 days [1, 2]. Among individuals the mean lifespan varies by approximately $\pm 15 \%$ [1]. As discussed below, there are circumstances in which even this relatively small normal variation can be important.

An accurate method to determine RBC lifespan that took advantage of emerging knowledge of the ABO system was first published by Winifred Ashby in 1919 [3, 4]. The differen-

\section{KARGER \\ Fax +497614520714 \\ Information@Karger.de}

www.karger.com (c) 2012 S. Karger GmbH, Freiburg

$1660-3796 / 12 / 0395-0302 \$ 38.00 / 0$

Accessible online at:

www.karger.com/tmh
Robert S. Franco, Ph.D.

Division of Hematology/Oncology

University of Cincinnati College of Medicine

The Vontz Center for Molecular Studies

3125 Eden Avenue, Cincinnati, OH 45267-0508, USA

Tel. +513 558-3241, Fax -6703, robert.franco@uc.edu 
tial agglutination technique used anti- $\mathrm{A}$ and anti-B antiserum to measure the lifespan of type $\mathrm{O} \mathrm{RBC}$ that were given to type A or type B recipients. This technique was difficult to perform since it included a quantitative agglutination of the subjects RBC in posttransfusion blood samples that was subject to many variables, followed by manual counting of the non-agglutinated RBC to quantitate the remaining transfused RBC. Furthermore, this method could not be applied to autologous RBC. Nevertheless, the Ashby technique was accurate, and remained the standard for measurement of allogeneic RBC lifespan for almost 40 years. It is an example of methods in which a representative sample of circulating RBC from the donor that can be distinguished from the recipient's $\mathrm{RBC}$ is infused into the recipient and identified in the circulation for (ideally) the lifetime of the RBC. Typically, the population of $\mathrm{RBC}$ that are infused represent the entire range of $\mathrm{RBC}$ ages in the donor, from $\mathrm{RBC}$ that were just released from the bone marrow to RBC that are senescent and due for removal from the circulation. In this type of 'population' study normal RBC are lost from the circulation immediately after reinfusion, and are removed in a linear manner for the greater part of the lifespan. Today, RBC population studies are performed with a label that is placed on the $\mathrm{RBC}$ ex vivo, making it possible to study both donor and autologous RBC.

The survival of labeled RBC can be analyzed in a number of ways to characterize the lifespan and help to identify mechanisms of RBC removal from the circulation. There are 3 basic time periods that must be considered. The first is the time it takes for the infused, labeled RBC to mix with the circulating unlabeled RBC. This is normally about $5 \mathrm{~min}$ [5], but may be longer in some patients, especially those with splenomegaly. During this time the concentration of labeled RBC cannot be determined, and any severely damaged RBC that are lost from the circulation are not accounted for unless there is an independent determination of the expected postinfusion concentration that can be compared with the measured value immediately after mixing occurs. For example, when measuring the survival characteristics of stored RBC a sample of fresh RBC (which are assumed to survive during the mixing period) with a different label may be co-infused. The second time period is the first $24 \mathrm{~h}$ after infusion of the labeled $\mathrm{RBC}$. This period is critically important since RBC that have been damaged by storage or labeling will typically be removed from the circulation during this time. RBC that make it through this window will usually have good long-term survival [6]. In the evaluation of cell storage media the U.S. Food and Drug Administration has relied mostly on 24-hour recovery, setting a minimum acceptable mean value of $75 \%$ with additional requirements for the range of values [7]. The third time period is long-term survival which is about 4 months. There has been added interest in the long-term RBC survival after storage and transfusion in recent years, as studies have become available that imply detrimental effects during this time period in patients who received blood that was stored for longer periods [8]. Accurate measurement of long-term survival requires determination of the amount of remaining labeled RBC for all or most of the RBC lifespan. The current standard label, ${ }^{51} \mathrm{Cr}$, is not well-suited for this task as explained below. Optimal determination of long-term survival also requires a steady state situation, with the important variable depending on the label used. For example, ${ }^{51} \mathrm{Cr}$ and other radioactive labels require a stable blood volume, while biotin and other flow cytometry-based labels require a stable number of total circulating RBC.

Another type of RBC lifespan study uses a synchronized age cohort of RBC that is labeled metabolically in vivo during a short period of time with either a radioactive or stable isotope. The isotope is typically delivered via orally administered labeled glycine, which is incorporated into both the heme and globin components of hemoglobin. This type of analysis does not average the survival of RBC generated for 4 months, but instead yields the survival of RBC that were all produced at about the same time. In a 'cohort' study it is possible to follow the various stages in the RBC lifespan, including release from the bone marrow during a time period that reflects normoblast differentiation kinetics, a long plateau period during which the only normal loss of label is related to presumably denatured and aggregated hemoglobin that has been removed from $\mathrm{RBC}$ that continue to circulate $[9,10]$, and finally the removal of $\mathrm{RBC}$ during a time period that represents the variability in RBC lifespan. An advantage of cohort studies is that all of the RBC coming out of the marrow are included in the analysis. This may not be true for population studies, since short-lived RBC will be underrepresented.

\section{Methods to Determine RBC Survival Characteristics}

\section{Methods for Labeling a Representative Population of Circulating $R B C$}

\section{${ }^{51} \mathrm{Cr}$}

${ }^{51} \mathrm{Cr}$ is a radioisotopic noncovalent population label. In the form of $\mathrm{Na}_{2}{ }^{51} \mathrm{CrO}_{4}$, it is incubated with packed or washed $\mathrm{RBC}$ [11-13] and incorporated into RBC as chromate VI through anion channels. Once inside the RBC it binds noncovalently to hemoglobin, and over $90 \%$ of the label is incorporated into RBC. After reinfusion, $\mathrm{Cr}$ elutes from the labeled $\mathrm{RBC}$ at a relatively constant rate of about $1 \%$ per day [12]. Advantages of this label are that it has been used extensively to measure human RBC survival characteristics and is available in approved formulations for this purpose. Labeling is convenient and standardized, and the counters required for quantitation are widely available. Its half-life (27.8 days) is well-suited for a 30-day RBC survival analysis which is adequate for many purposes. A disadvantage is that in many countries ${ }^{51} \mathrm{Cr}$ cannot be used due to radioactivity. Even where it can be used, such as the USA, it is avoided in chil- 
dren and pregnant women. In research studies blood samples may be considered to be radioactive waste and must be handled accordingly, making parallel assays difficult. While standard tables, derived by assuming a linear survival of 115 days [14] or by comparison with diisopropylphosphofluoridate $\left(\mathrm{DF}^{32} \mathrm{P}\right)$-labeled RBC [15], are available to correct for elution up to 30 days, these are average values and elution for individuals and RBC subpopulations [16] may vary significantly. The combination of elution and decay makes it difficult to follow the labeled RBC accurately for the entire RBC lifespan.

\section{Biotin}

Biotin is a nonradioactive covalent population label. Washed $\mathrm{RBC}$ are reacted with $\mathrm{N}$-hydroxysuccinimide(NHS)-biotin or sulfo-NHS-biotin to covalently label membrane proteins with biotin $[1,2]$. RBC from postinfusion blood samples are reacted with fluorescently conjugated streptavidin and the biotin-labeled RBC quantitated as a percentage of the total RBC by flow cytometry. The nonradioactive biotin label has been used in newborns to determine RBC volume and lifespan [17] and has been shown to correlate with ${ }^{51} \mathrm{Cr}$-labeled $\mathrm{RBC}[18,19]$. There is some loss of label from the $\mathrm{RBC}$ as they age, but all the labeled $\mathrm{RBC}$ remain in the positive flow cytometric region, and thus the loss of label has no effect on quantitation. This, together with the very high number of RBC that can be analyzed in each postinfusion sample, and the very low false-positive number in the cytometer, makes it possible to accurately determine the entire RBC lifespan using microliter-sized blood samples. Since it is possible to place different levels of biotin on separate cell populations and distinguish them in the flow cytometer, RBC lifespan can be determined for up 3 populations of RBC concurrently [2]. The biotin-labeled RBC can be examined with multicolor flow cytometry to determine how variables change as the $\mathrm{RBC}$ age. Examples include fetal hemoglobin ( $\mathrm{HbF}$ )-containing RBC and externalized phosphatidylserine [19-22]. The labeled RBC can be isolated by means of streptavidin-coated magnetic beads and assayed by high-performance liquid chromatography (HPLC) or other methods [1]. Examples of this type of analysis include $\mathrm{HbF}$ and $\mathrm{HbA} 1 \mathrm{c}$ quantitation [1, 19-22]. The major potential disadvantage of the biotin label is the development of antibodies against biotinylated RBC. In one report [23] transient antibodies were detected using an agglutination technique in 3 of 20 subjects that were given biotin-labeled RBC. None of these antibodies appeared to have an effect on RBC lifespan, and none could be detected after 1 year.

\section{Methods Utilizing Metabolic Precursors or Products}

\section{Carbon Monoxide}

Carbon monoxide $(\mathrm{CO})$ can be used for the quantitation of heme turnover. This method is based on the principle that the catabolism of heme is the only endogenous source of $\mathrm{CO}$, with 1 molecule of $\mathrm{CO}$ resulting from each heme. Therefore, $\mathrm{CO}$ production is directly related to heme turnover [24-28]. However, hemoglobin accounts for only about $80 \%$ of heme turnover, and this may vary in disease states. Production of CO may be quantitated over several hours by means of a rebreathing system [24-28], or an estimate made by measurement of alveolar CO [29-31]. This method has the advantage that measurement of $\mathrm{CO}$ production can be used to measure heme turnover serially over a relatively short time period. Disadvantages include that while heme turnover can be reliably determined with the aid of a rebreathing system, there is uncertainty concerning the contribution of other hemecontaining proteins. Alveolar sampling, while convenient, is subject to environmental influences.

\section{Labeled Glycine}

This is a stable isotope metabolic cohort label. Glycine is a precursor of heme and globin, and may be given orally to label the hemoglobin in RBC. Glycine is incorporated into $\mathrm{RBC}$ precursors over the entire range of normoblasts that synthesize hemoglobin, and thus the amount of label in the blood increases for up to 25 days after oral administration [32]. It has the advantages that no ex vivo labeling is required, and all RBC released from the bone marrow are included in the analysis. A disadvantage is that this method requires mass spectroscopic analysis.

\section{Applications}

RBC survival determinations are rarely performed for clinical purposes, but there are a number of investigational circumstances in which they are useful, including: i) evaluation of RBC storage and pathogen inactivation [33-35]; ii) studies of the pathophysiology of sickle cell disease [19-22]; iii) the importance of RBC lifespan in diabetes as an explanation of mismatches between blood glucose and HbA1c [1]; iv) studies of the optimum RBC transfusion product for premature newborns [17]; v) poorly understood anemias including those associated with chronic inflammation [36] and the elderly; vi) investigations of RBC aging and senescence. Studies of transfusion products require a population-type, ex vivo label. However, the metabolic glycine-based cohort label may be ideal for studies of disease pathophysiology.

\section{The Biotin Label in RBC Aging Studies}

The most useful label for RBC aging studies is biotin. This label not only allows precise quantitation of RBC survival for the full lifespan, but also makes possible detailed evaluation of changes that occur in the circulation as the RBC age. 


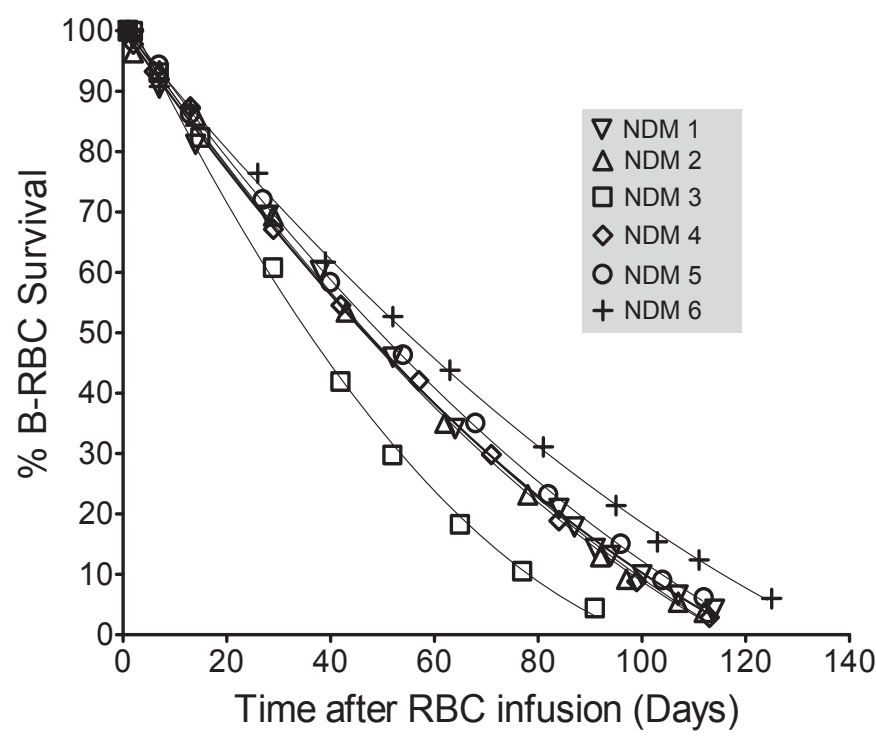

Fig. 1. Survival of normal RBC labeled with biotin. Six hematologically normal subjects (NDM1-NDM6) are shown. The 1-day recovery, compared to 10-20 min after reinfusion, was $96.8 \pm 1.4$ (1 standard deviation) $\%$. The value at 1 day was taken as $100 \%$ for evaluation of long-term lifespan. This research was originally published in Blood in 2008 [1].

Time-Dependent Changes in the Age of Biotin-Labeled RBC after Reinfusion

In animal studies it is possible to label all the $\mathrm{RBC}$ in vivo with biotin with an intravenous injection of sulfo-NHS-biotin [3743]. At subsequent times the biotin-negative RBC are all younger than the time since administration of the labeling reagent, and the biotin-positive RBC are all older than that time. The negative RBC include reticulocytes, which may bias any assays performed on those RBC. It is also possible in animals to combine in vivo biotinylation with another label to follow a true age cohort as the RBC age in the circulation [44]. In human studies RBC are labeled ex vivo, and in a typical adult reinfusion of $10 \mathrm{ml}$ of labeled $\mathrm{RBC}$ will give about $0.5 \%$ positive $\mathrm{RBC}$ in the flow cytometer immediately after reinfusion and mixing in the circulation. Initially, the labeled and unlabeled RBC in the circulation should have identical properties, with ages ranging from 0 days to the maximum $\mathrm{RBC}$ lifespan. At subsequent time points the age of the labeled RBC will range from the time since reinfusion to the maximum lifespan, and the average age of the labeled $\mathrm{RBC}$ will therefore increase while unlabeled RBC maintain a constant steady state age distribution and average age. If all of the RBC are removed from the circulation at the same age, e.g. 115 days, the disappearance of labeled RBC will be linear and intercept the X-axis at that age. In practice, for most hematologically normal controls the disappearance is linear for most of the lifespan and then forms a tail [1,2] (fig. 1). A technique has been published, based on original work in the animal trap and release literature [45], for calculating the mean age of the labeled RBC both at and subsequent to the time of labeling, regardless of

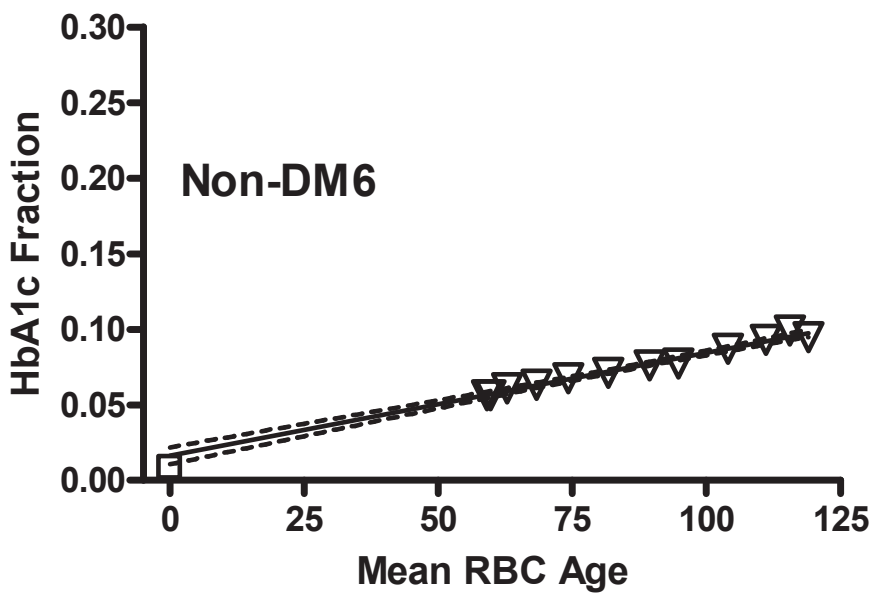

Fig. 2. RBC were labeled with biotin and reinfused into a normal subject. At the times indicated labeled cells were isolated with streptavidincoated magnetic beads and the fraction HbA1c determined by HPLC. The mean RBC age was calculated for each time point (inverted triangles) according to [45]. The open square represents the value for TfR+ reticulocytes isolated with anti-TfR-coated magnetic beads and assayed the same way. These data indicate that the amount of HbA1c increases linearly as the RBC age. This research was originally published in Blood in 2008 [1].

the shape of the curve. This is useful in plotting changes that occur as the RBC age. However, for many purposes a simpler analysis is adequate, including a linear extrapolation to the $\mathrm{X}$ axis or a time to $50 \%$ removal. While it is possible to study a relatively pure population of old $\mathrm{RBC}$ using this technique by allowing them to age in vivo, it is not possible to study young $\mathrm{RBC}$ without the presence of older RBC. This limitation can be partially overcome by isolating for study very young unlabeled reticulocytes by means of magnetic beads coated with an antibody to the transferrin receptor [1].

\section{Assays of Aging RBC Based on Multicolor Flow Cytometry}

Using the biotin label and 2 fluorescent colors it is possible to measure any property that can be analyzed by flow cytometry as RBC age. The first color (e.g. FITC) is used to identify the biotin-labeled RBC, and the second color (e.g. phycoerythrin) to evaluate the property. Since a large number of RBC are counted this analysis can be continued for essentially the entire RBC lifespan. In animal studies with in vivo biotinylation, this technique has been used to determine cell age-related changes in membrane immunoglobulin [43, 46], aminophospholipid translocase (flippase) activity [47], enzyme activities [40], and many other properties $[38,39,42]$ In human studies with ex vivo biotinylation, measured variables include $\mathrm{HbF}$-containing RBC [19, 20, 22], RBC with external phosphatidylserine [21], and the time for disappearance of reticulocytes [19].

\section{Assays of Aging RBC Based on Magnetic Isolation}

Another powerful analytical approach, which can be applied with either in vivo or ex vivo labeling, is the isolation of bi- 
otin-labeled RBC with the aid of streptavidin-coated magnetic beads [1]. For human studies in which $10 \mathrm{ml}$ of packed labeled $\mathrm{RBC}$ are reinfused, there are initially about $0.5 \%$ labeled RBC in the circulation. This corresponds to $5 \mu \mathrm{l}$ of labeled RBC per ml of packed RBC. After $90 \%$ of the labeled $\mathrm{RBC}$ are removed from the circulation, and the remaining labeled RBC in a normal subject are at least about 110 days old, there are about $0.5 \mu \mathrm{l}$ of labeled RBC per ml of packed $\mathrm{RBC}$. Any assay that can be performed on these volumes of $\mathrm{RBC}$ can therefore be applied to aging RBC. For example, hemoglobin composition of aging sickle $\mathrm{RBC}$ and the rate of formation of HbA1c have been determined by HPLC [1] (fig. 2).

\section{Conclusion}

It is nearly 100 hundred years since the first accurate measurements of red cell lifespan and the first clues of their age- dependent removal from the circulation. During this time there has been great interest in mechanisms involved in determining the proper time for removal and marking the cell for uptake by the reticuloendothelial system. Information concerning the changes that take place as a red cell ages is central to these questions, and the early differential agglutination techniques used for measuring lifespan were well suited for these studies since they allowed the isolation of aged RBC. However, they were not applied in this way, and their complete replacement by radioisotope labels in the mid 20th century made such studies impossible. Only recently with the introduction of the biotin label has a method become available that allows the detection, analysis, and isolation of aging $\mathrm{RBC}$, and thus detailed studies of their properties.

\section{Disclosure Statement}

The author declared no conflict of interest.

\section{References}

$\checkmark 1$ Cohen RM, Franco RS, Khera PK, Smith EP, Lindsell CJ, Ciraolo PJ, Palascak MB, Joiner CH Red cell life span heterogeneity in hematologically normal people is sufficient to alter HbA1c. Blood 2008;112:4284-4291.

2 Mock DM, Matthews NI, Zhu S, Strauss RG Schmidt RL, Nalbant D, Cress GA, Widness JA Red blood cell (RBC) survival determined in humans using RBCs labeled at multiple biotin densities. Transfusion 2011;51:1047-1057.

$\checkmark 3$ Ashby W: The determination of the length of life of transfused blood corpuscles in man. J Exp Med 1919;29:267-281.

4 Franco RS: The measurement and importance of red cell survival. Am J Hematol 2009;84:109-114.

5 Mollison PL: Blood-group antibodies and red-cell destruction. Br Med J 1959;2:1123-1130.

6 Mollison PL, Engelfriet CP, Contreras M: The Transfusion of Red Cells; Blood Transfusion in Clinical Medicine. Oxford, Blackwell, 1987, pp 95-159.

7 Dumont LJ, AuBuchon JP: Evaluation of proposed FDA criteria for the evaluation of radiolabeled red cell recovery trials. Transfusion 2008; 48:1053-1060.

8 Wang D, Sun J, Solomon SB, Klein HG, Natanson C: Transfusion of older stored blood and risk of death: a meta-analysis. Transfusion 2012;52:11841195.

$\checkmark 9$ Willekens FL, Bosch FH, Roerdinkholder-Stoelwinder B, Groenen-Dopp YA, Werre JM: Quantification of loss of haemoglobin components from the circulating red blood cell in vivo. Eur J Haematol 1997;58:246-250.

10 Willekens FL, Roerdinkholder-Stoelwinder B, Groenen-Dopp YA, Bos HJ, Bosman GJ, van den Bos AG, Verkleij AJ, Werre JM: Hemoglobin loss from erythrocytes in vivo results from spleen-facilitated vesiculation. Blood 2003;101:747-751.

11 Klein HG, Anstee DJ: Appendix 2 and Appendix 6; Blood Transfusion in Clinical Medicine. Malden, MA, Blackwell, 2005, pp 846-850.
Recommended methods for radioisotope red-cell survival studies. A report by the ICSH panel on diagnostic applications of radioisotopes in haematology. Br J Haematol 1971:21:241-250.

13 International Committee for Standardization in Haematology: Recommended method for radioisotope red-cell survival studies. Br J Haematol 1980; 45:659-666.

14 Garby L, Mollison PL: Deduction of mean red-cell life-span from $51 \mathrm{Cr}$ survival curves. Br J Haematol 1971:20:527-536.

15 Bentley SA, Glass HI, Lewis SM, Szur L: Elution correction in $51 \mathrm{Cr}$ red cell survival studies. $\mathrm{Br} \mathrm{J}$ Haematol 1974;26:179-184.

16 Valeri CR, Kuehl GV, Skrabut EM, Bechthold DA, Vecchione JJ, Harkness DR, EMERSON CP: Studies on the in vivo elution of $51 \mathrm{Cr}$ from baboon red blood cells. Vox Sang 1981;40:338-345.

17 Strauss RG, Mock DM, Widness JA, Johnson K, Cress G, Schmidt RL: Posttransfusion 24-hour recovery and subsequent survival of allogeneic red blood cells in the bloodstream of newborn infants. Transfusion 2004;44:871-876.

18 Mock DM, Lankford GL, Widness JA, Burmeister LF, Kahn D, Strauss RG: Measurement of red cell survival using biotin-labeled red cells: validation against ${ }^{51} \mathrm{Cr}$-labeled red cells. Transfusion 1999;39: 156-162.

19 Franco RS, Lohmann J, Silberstein EB, MayfieldPratt G, Palascak M, Nemeth TA, Joiner CH, Weiner M, Rucknagel DL: Time-dependent changes in the density and hemoglobin F content of biotinlabeled sickle cells. J Clin Invest 1998;101:27302740.

20 Franco RS, Yasin Z, Palascak MB, Ciraolo P, Joiner CH, Rucknagel DL: The effect of fetal hemoglobin on the survival characteristics of sickle cells. Blood 2006:108:1073-1076.

21 Yasin Z, Witting S, Palascak MB, Joiner CH, Rucknagel DL, Franco RS: Phosphatidylserine externalization in sickle red blood cells: associations with cell age, density, and hemoglobin F. Blood 2003:102:365-370.
22 Franco RS, Yasin Z, Lohmann JM, Palascak MB Nemeth TA, Weiner M, Joiner CH, Rucknagel DL: The survival characteristics of dense sickle cells. Blood 2000;96:3610-3617.

23 Cordle DG, Strauss RG, Lankford G, Mock DM: Antibodies provoked by the transfusion of biotinlabeled red cells. Transfusion 1999;39:1065-1069.

$\checkmark 24$ Coburn RF, Blakemore WS, Forster RE: Endogenous carbon monoxide production in man. J Clin Invest 1963;42:1172-1178.

25 Coburn RF, Williams WJ, Kahn SB: Endogenous carbon monoxide production in patients with hemolytic anemia. J Clin Invest 1966;45:460-468.

26 White P, Coburn RF, Williams WJ, Goldwein MI, Rother ML, Shafer BC: Carbon monoxide production associated with ineffective erythropoiesis. J Clin Invest 1967;46:1986-1998.

27 Coburn RF: Endogenous carbon monoxide production. N Engl J Med 1970;282:207-209.

28 Coburn RF: Endogenous carbon monoxide metabolism. Annu Rev Med 1973:24:241-250.

-29 Furne JK, Springfield JR, Ho SB, Levitt MD: Simplification of the end-alveolar carbon monoxide technique to assess erythrocyte survival. J Lab Clin Med 2003;142:52-57.

30 Mitlyng BL, Chandrashekhar Y, Furne JK, Levitt MD: Use of breath carbon monoxide to measure the influence of prosthetic heart valves on erythrocyte survival. Am J Cardiol 2006;97:1374-1376.

31 Strocchi A, Schwartz S, Ellefson M, Engel RR, Medina A, Levitt MD: A simple carbon monoxide breath test to estimate erythrocyte turnover. J Lab Clin Med 1992;120:392-399.

32 Shemin D, Rittenberg D: The life span of the human red blood cell. J Biol Chem 1946;166:627-636.

33 Cancelas JA, Dumont LJ, Rugg N, Szczepiorkowski ZM, Herschel L, Siegel A, Pratt PG, Worsham DN Erickson A, Propst M, North A, Sherman CD, Mufti NA, Reed WF, Corash L: Stored red blood cell viability is maintained after treatment with a second-generation S-303 pathogen inactivation process. Transfusion 2011;51:2367-2376. 
34 Cancelas JA, Rugg N, Pratt PG, Worsham DN Pehta JC, Banks K, Davenport RD, Judd WJ: Infusion of P-Capt prion-filtered red blood cell products demonstrate acceptable in vivo viability and no evidence of neoantigen formation. Transfusion 2011;51:2228-2236.

35 Cancelas JA, Rugg N, Fletcher D, Pratt PG, Worsham DN, Dunn SK, Marschner S, Reddy HL, Goodrich RP: In vivo viability of stored red blood cells derived from riboflavin plus ultraviolet lighttreated whole blood. Transfusion 2011;51:14601468.

-36 Mitlyng BL, Singh JA, Furne JK, Ruddy J, Levit MD: Use of breath carbon monoxide measurements to assess erythrocyte survival in subjects with chronic diseases. Am J Hematol 2006;81:432-438.

37 Suzuki T, Dale GL: Biotinylated erythrocytes: in vivo survival and in vitro recovery. Blood 1987;70: 791-795.
38 Suzuki T, Dale GL: Senescent erythrocytes: isolation of in vivo aged cells and their biochemical characteristics. Proc Natl Acad Sci U S A 1988;85:16471651.

39 Suzuki T, Dale GL: Membrane proteins in senescent erythrocytes. Biochem J 1989;257:37-41.

40 Zimran A, Forman L, Suzuki T, Dale GL, Beutler E: In vivo aging of red cell enzymes: study of biotinylated red blood cells in rabbits. Am J Hematol 1990;33:249-254.

41 Dale GL, Norenberg SL: Density fractionation of erythrocytes by percoll/hypaque results in only a slight enrichment for aged cells. Biochim Biophys Acta 1990;1036:183-187.

42 Dale GL, Daniels RB, Beckman J, Norenberg SL: Characterization of senescent red cells from the rabbit; in Magnani M, DeFlora A (eds): Red Blood Cell Aging. New York, NY, Plenum Press, 1991, pp 93-103.
43 Dale GL, Daniels RB: Quantitation of immunoglobulin associated with senescent erythrocytes from the rabbit. Blood 1991;77:1096-1099.

44 Gifford SC, Yoshida T, Shevkoplyas SS, Bitensky MW: A high-resolution, double-labeling method for the study of in vivo red blood cell aging. Transfusion 2006;46:578-588.

45 Lindsell CJ, Franco RS, Smith EP, Joiner CH, Cohen RM: A method for the continuous calculation of the age of labeled red blood cells. Am J Hematol 2008;83:454-457.

46 Christian JA, Rebar AH, Boon GD, Low PS: Senescence of canine biotinylated erythrocytes: increased autologous immunoglobulin binding occurs on erythrocytes aged in vivo for 104 to 110 days. Blood 1993;82:3469-3473.

47 DeJong K, Bhagat A, Emerson RK, Kuypers FA Flippase activity decreases throughout erythrocyte life-span in normal and sickle mice. ASH 2006;108: abstr 3786 . 